Bull.Fac, Agric.,Cairo Univ.,62:355-361 (2011).

\title{
EFFECT OF GAMMA RAYS ON PROPAGATION OF Zantedeschia aethiopica Spreng BY TISSUE CULTURE TECHNIQUE
}

(Received: 18. 5. 2011)

\author{
By \\ A.M.S. Arafa, M.M.M. Hussein, F. H. Nofal" and A. F. M. Hosny ${ }^{* * *}$ \\ Ornamental Horticulture Department ; "Department of Agricultural Botany, Plant Physiology Division, \\ Faculty of Agriculture, Cairo University, Giza, Egypt and ${ }^{* *}$ Horticulture Research Department, \\ Agricultural Research Center, Giza, Egypt.
}

\begin{abstract}
The average of two seasons investigation was initiated at the Laboratory of Plant Tissue Culture, Agricultural Development Systems Project (ADSP), Ministry of Agriculture, to disclose the individual and combined effects of five gamma ray doses $(0,3,6,9,12$ and $15 \mathrm{kr})$ and various growth substances supplementation to MS media, in vitro, on growth and root parameters of Zantedeschia aethiopica (L.) Spreng, shoot tips.

The obtained results revealed that survival (\%) increased up to the third day, then declined gradually. Survival (\%) decreased progressively as irradiation doses $(\mathrm{Kr})$ increased, but plantlets treated with doses higher than $6.0 \mathrm{Kr}$ died at the seventh day.

In general, 3.0 Kr irradiation individually at most growth substances, increased the number of shoot, shoots length, number of roots, and root length compared to the control.

The response of the studied parameters to various growth substances individually or combined with gamma ray doses was variable. The highest values of shoot length $(\mathrm{cm})$ and the number of shoots resulted significantly by $3.0 \mathrm{Kr}$ irradiation combined with $4.0 \mathrm{mg} \mathrm{BA} / \mathrm{l}$ and $3.0 \mathrm{Kr}$ irradiation combined with $3.0 \mathrm{mg}$ TDZ/l, respectively in comparison to most other treatments. Moreover, the number of roots and root length were significantly the largest due to $3.0 \mathrm{Kr}$ gamma rays with $5 \mathrm{mg}$ NAA/l, successively compared with most other treatments. Whereas, the lowest values of shoot length $(\mathrm{cm})$ and the number of shoots were produced by $6.0 \mathrm{kr}$ gamma rays combined with $0.0 \mathrm{mg} \mathrm{BA} / \mathrm{L}$ and $0.0 \mathrm{mg} \mathrm{TDZ} / \mathrm{l}$, on concession.
\end{abstract}

Key words: gamma rays, in vitro propagation, Zantedeschia aethiopica.

\section{INTRODUCTION}

Zantedeschia aethiopica (L.) Spreng (Calla, Cally lily, arum lily), family Araceae is a perennial stemless herb with thick fleshy subterranean much branched rhizomes; such underground storage organ is thickened, fleshy and has been classified as a crom, tuber or rhizome (Bryan, 2002 ). These plants are native to South Africa, Cape Province Natal, Transvaal Malawi to Angola and Lesotho, widly naturalized in tropical and subtropical regions (Niederwieser et al., 2002). They occur as a roadside wild flower in its native zones; suitable for containers and borders in cool to intermediate glasshouse to conservatory, a pot plant and cut blooms. They are useful as focal specimen in shaded borders, in bogygradens and marginal aquatics. (Corr and Wilkins, 2005).
Micropropagation or plant tissue culture provides numerous numbers of new plants-that are identical to the mother plant by using a small piece of plant. Different types of plants are now propagated extensively through in vitro techniques. Arafa and Ebrahim (2001) consummated various investigations to culture Calla lily in vitro under different conditions.

The behaviors of each consecutive micropropagation of Zantedeschia sp. plants were clearly influenced by many factors as cytokinins (TDZ, BA) and auxin (NAA) ( Koech et al., 2002; Chang et al., 2003; Ebrahim , 2004 and El-Shamy et al., 2008).

Irradiation of seeds or shoot or root tips or different parts with different doses of gamma rays is an effective tool to encourage survival (\%), growth and flowering characters, as well as 
creating new cultivars.

However, the suitable doses of radiation for different plants are variant. Kovacs and Keresztes (2002) mentioned that gamma rays produce hydrogen peroxide and free radicals which are themselves activators, stimulators and mutagenic through molecular effects. Many investigators as Khalil et al. (2001) on Foeniculum vulgare and Nigella sativa, Badr et al. (2004) on Gompherna globosa and Seung et al.(2007) on Arabidopsis thaliana mentioned that low doses of gamma rays stimulated various characters. High doses of irradiation have reductive or lethal effects. This inhibition may be rendered apices appeared histologically inert or breakdown of meristimatic cells and cell nuclear damage.

The prospective of the present investigation was to disclose the influence of various doses of gamma rays irradiation and providing MS media with auxin alpha-naphthalene acetic acid (NAA) and cytokinins benzyladenine (BA), thidiazuron (TDZ) on growth parameters of Zantedeschia aethiopica (L.) Spreng in in vitro culture.

\section{MATERIAL AND METHODS}

Greenhouse-grown plants of Zantedeschia aethiopica (L.) Spreng, with rhizome diameter 6$7 \mathrm{~cm}$ were used for this investigation during the 2007-2009 seasons.

Rhizome- bud explants $(1.0 \mathrm{~cm}$ length) were surface sterilized under complete aseptic conditions in a sterilized laminar air-flow hood, by immersion in $4.0 \% \mathrm{NaOCl}$ solution for 5 minutes, as suggested by Arafa and Ebrahim (2001). After sterilization, the explants were rinsed in a sterile distilled water to remove all traces of chlorine.

Outside tissues were removed, apical meristems were cultured on MS (Murashige and Skoog, 1962) basal medium containing $10 \mathrm{~g}$ sucrose/l and 6.0 agar/l. Developing explants were recultured at four weeks intervals, in order to obtain sufficient number of plantlets.

Plantlets $(6 \mathrm{~mm}$ long) were gamma irradiated with a one fold dose of $0,3,6,9,12$ and $15 \mathrm{kr}$ from cobalt source at the Atomic Energy Authority. Irradiation dose was measured at the planned location of the sample before treatment. Samples were positioned between two sheets of Lucite. The irradiation field was $15 \times 15 \mathrm{~cm}$ and was homogenous. Depth dose was calculated. Dose rate was 2.37rad./ second. Exposure time was equivalent for treatments of $0,3,6,9,12$ and $15 \mathrm{kr}$ of gamma rays. Irradiated plantlets were sterilized in aqueous $\mathrm{NaOCl} 4.0 \%$ for five minutes, After sterilization, the explants were rinsed three times in sterilized distilled water to remove all traces of chlorine and sub-cultured on MS basal media $(\mathrm{pH}$ 5.7) provided with $10 \mathrm{~g}$ sucrose and $6 \mathrm{~g}$ agar/l to determine percentage of survival, for eight days.

The results disclosed that irradiation doses more than $6 \mathrm{kr}$ were lethal, so plantlets of the 0,3 and $6 \mathrm{kr}$ doses were used to test the effect of supplementing basal media (full strength MS) with different concentrations of growth regulators namely; $0.0,1.0,2.0,3.0,4.0$ and $5.0 \mathrm{mg} / 1$. of (BA), (TDZ) and (NAA) growth substances, individually.

Eight weeks later, the following parameters were recorded for each plantlet: number of shoots, shoot length $(\mathrm{cm})$, number of root, root length (cm).

The layout of the investigation was complete randomized factorial design (3 gamma doses x 6 concentrations) with six replications for each treatment. The obtained data were analysed according to a statistical analysis programe (SAS, 1994); comparing between figures was done using L.S.D. at 5\% level, as reported by Snedecor and Cochran (1980).

\section{RESULTS AND DISCUSSION}

\subsection{Effect of irradiation doses on survival (\%)}

It appeared from the data in Table (1) that irradiation of Zantedeschia plantlets with various doses of gamma rays significantly reduced survival percentages in comparison to the control (unirradiated). The percentages decreased gradually as gamma ray doses increased. Survival began in the second day for most irradiation doses, but at the third day for the control. Then, it decreased progressively day by day, till the seventh and it became constant in the eighth day. Shoots treated with $15 \mathrm{Kr}$ dose died at the sixth day, whereas those irradiated with gamma rays at 9 and $12 \mathrm{Kr}$ died at the eighth day. These results are in agreement with those of Fereol et al. (1996) on Alpinia purpurata; Bakrey and Ismail (2002) on papaya; El-Shakhs et al. (2007) on canary island palm, livistona, sabal and washingtonia and Abu El-Leil (2008) on black seed and cumin, which reported that low doses of gamma ray stimulated survival (\%), but raising irradiation doses led to a progressive decrease in such parameter. Kovacs and Keresztes (2002) explained lethality of explants at high gamma rays doses by breakdown of meristimatic cells and cell nuclear damage. 
3.2. Effect of gamma rays and various growth substances on some growth parameters of Zantedeschia shoot tips

3.2.1. Impact of irradiation doses individually, irrespective of substances

Data presented in Tables (2 to 4) disclosed that irradiation of Zantedeschia shoot tips with $3.0 \mathrm{Kr}$ dose led significantly to the highest number and longest shoots and roots compared to the control and $6.0 \mathrm{Kr}$ dose, in most cases. The radiation doses caused significant reductions of shoot length and number of shoots and roots in comparison with the control. Such findings showed a similar trend in average of two seasons. Puchooa (2005) on Anthurium and Tangpong et al.(2009) on Anubias congensis obtained similar finding, that low irradiation doses stimulated shoot and root formation and plant height, but high doses reduced such parameters .

\subsubsection{Effect of benzyladenine (BA) and} radiation doses

It is clear from the data in Table (2) that the influence of BA on various growth characters was not similar. Number and shoot length of shoot tips showed a gradual significant increase as BA concentrations were raised. On the other hand, root length and root number showed the opposite trend.

Concerning the effect of the combined treatments (radiation and BA rates), it appeared that the control produced the largest number of roots and root length. While the largest number of shoots $(8.3)$ and the longest shoots $(11.35 \mathrm{~cm})$ resulted due to $3.0 \mathrm{Kr}$ irradiation combined with $4.0 \mathrm{mg} \mathrm{BA} / 1$, but the largest number of roots (4.0) and root length $(4.04 \mathrm{~cm})$ resulted from the treatment of $3.0 \mathrm{Kr}$ irradiation dose combined with $1.0 \mathrm{mg} \mathrm{BA} / \mathrm{l}$ and the lowest number of shoots $(1.3)$ and shoot length $(1.75 \mathrm{~cm})$ resulted due to the treatment of $6.0 \mathrm{Kr}$ combined with $0.0 \mathrm{mg} \mathrm{BA} / 1$, The least number of roots and root length resulted due to $0.0 \mathrm{Kr}$ combined with $5.0 \mathrm{mg} \mathrm{BA} / \mathrm{l}$. Such combined treatment resulted in the significant highest values in comparison with most other ones.

\subsubsection{Effect of thidiazuron (TDZ) and irradiation doses}

The impact of TDZ concentrations on various aerial parts and root characters was variable, as shown in Table (3). All levels of TDZ increased the number of shoots and length of shoots over the control $(0.0 \mathrm{mg}$ TDZ/l), based on the average of the two seasons. This character was raised gradually with increasing TDZ up to $3.0 \mathrm{mg}$
TDZ/l) concentration, then it declined progressively. While, the low levels of TDZ led to produced shorter roots compared to the control.

Shoot length and the number of shoots increased gradually by increasing TDZ levels up to $3.0 \mathrm{mg} / \mathrm{L}$, then they were raised. But for the number and root length per plant, the $4.0 \mathrm{mg}$ level raised it compared with the control. Variations between most of TDZ concentrations were significant based on the average of the two seasons.

It was clear from Table (3) that the treatment of $3.0 \mathrm{Kr}$ in radiation dose combined with $3.0 \mathrm{mg}$ TDZ/l, resulted in the highest number of shoots (7.3) and the longest shoots $(10.32 \mathrm{~cm})$. But, the longest roots and largest number of roots occurred due to $3.0 \mathrm{Kr}$ irradiation combined with $4.0 \mathrm{mg}$ $\mathrm{TDZ} / \mathrm{l}$, based on the average of the two seasons.

However, the treatment of $1.0 \mathrm{mg}$ TDZ/1 without irradiation gave the shortest roots $(1.74$ $\mathrm{cm})$. While, the least number of roots (1.0) was produced by $6.0 \mathrm{Kr}$ gamma rays at $1.0 \mathrm{mg} \mathrm{TDZ} / \mathrm{L}$ concentration, based on the average of the two seasons.

The differences between such treatments producing the highest and lowest values and other ones were significant, in most cases, at average two seasons.

\subsubsection{Effect of alpha-naphthalene acetic acid (NAA) and radiation doses}

The results in Table (4) revealed that the values of shoot length, and number of shoots were raised progressively as NAA concentrations increased up to $4.0 \mathrm{mg} / \mathrm{l}$, then they declined; while, number of shoots/plant happened with increasing NAA level up to $5.0 \mathrm{mg} / \mathrm{l}$, but the values of root length and root number were raised till $5.0 \mathrm{mg} / \mathrm{l}$.

The lower values of the number of shoot and shoot length occurred due to 1.0 and $2.0 \mathrm{mg} / \mathrm{l}$ NAA, but the control $(0.0 \mathrm{mg} / \mathrm{l} \mathrm{NAA})$ gave lower values of number and length $(\mathrm{cm})$ of roots, based on the average of the two seasons. Such values were significantly higher or lower than most other concentrations.

As for the combined treatments (doses of gamma rays and NAA concentrations) it appeared that the higher values of number and length of shoots and number and length of roots occurred due to $3.0 \mathrm{Kr} \times 4.0 \mathrm{mg} / \mathrm{L}$ NAA and $3.0 \mathrm{Kr}$ at 5.0 $\mathrm{mg} / \mathrm{l}$ NAA, respectively.

On the other hand, the lowest values of shoot number and length resulted by the treatment of 6.0 Kr gamma rays combined with 5.0mg NAA; 


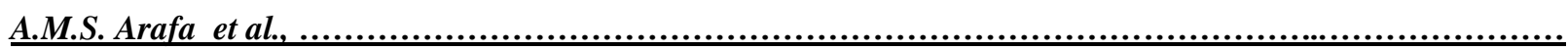

Table(1) Effect of irradiation doses through 8 days on survival (\%) of Zantedeschia aethiopica

\begin{tabular}{|c|c|c|c|c|c|c|c|c|c|}
\hline \multirow{3}{*}{$\begin{array}{c}\text { Gamma rays } \\
\mathrm{Kr}\end{array}$} & \multicolumn{9}{|c|}{ Survival (\%) } \\
\hline & \multicolumn{9}{|c|}{ Time (days) } \\
\hline & 1 & 2 & 3 & 4 & 5 & 6 & 7 & 8 & Mean \\
\hline 0 & 100 & 100 & 100 & 100 & 100 & 100 & 100 & 100 & 100.00 \\
\hline 3 & 100 & 100 & 80 & 80 & 70 & 60 & 60 & 60 & 76.25 \\
\hline 6 & 100 & 100 & 70 & 50 & 50 & 30 & 30 & 30 & 57.50 \\
\hline 9 & 100 & 80 & 70 & 40 & 40 & 20 & 10 & 0 & 45.00 \\
\hline 12 & 100 & 70 & 50 & 30 & 20 & 10 & 10 & 0 & 36.25 \\
\hline 15 & 100 & 60 & 40 & 20 & 10 & 0 & 0 & 0 & 28.75 \\
\hline Mean & 100.00 & 85.00 & 68.33 & 53.33 & 48.33 & 36.67 & 35.00 & 31.67 & \\
\hline $\begin{array}{c}\text { L.S.D 5\% Time } \\
\text { Gamma } \\
\text { Interaction }\end{array}$ & & & & & & & & & \\
\hline
\end{tabular}

Table(2):Effect of BA and three doses of gamma rays on Zantedeschia aethiopica shoot number, shoot length, root number and root length after 8 weeks (average of two seasons)

\begin{tabular}{|c|c|c|c|c|c|c|c|c|c|c|c|c|c|c|c|c|}
\hline \multirow{3}{*}{ BA $\mathrm{mg} / \mathrm{l}$} & \multicolumn{4}{|c|}{ Shoot number } & \multicolumn{4}{|c|}{ Shoot length(cm) } & \multicolumn{4}{|c|}{ Root number } & \multicolumn{4}{|c|}{ Root length(cm) } \\
\hline & \multicolumn{16}{|c|}{ Doses of gamma rays $(\mathrm{Kr})$} \\
\hline & 0 & 3 & 6 & Mean & 0 & 3 & 6 & Mean & 0 & 3 & 6 & Mean & 0 & 3 & 6 & Mean \\
\hline 0 & 1.9 & 3.6 & 1.3 & 2.27 & 2.34 & 5.85 & 1.75 & 3.31 & 3.3 & 4.0 & 2.3 & 3.20 & 2.63 & 4.04 & 1.97 & 2.88 \\
\hline 1 & 2.6 & 5.3 & 2.0 & 3.30 & 3.10 & 7.75 & 2.32 & 4.39 & 2.0 & 2.9 & 1.6 & 2.17 & 1.97 & 4.53 & 1.47 & 2.66 \\
\hline 2 & 2.9 & \begin{tabular}{|l|}
5.9 \\
\end{tabular} & 2.3 & 3.70 & 3.46 & 8.65 & 2.59 & 4.90 & 1.3 & 1.9 & 0.9 & 1.37 & 1.58 & 3.64 & 1.18 & 2.13 \\
\hline 3 & 4.3 & 6.3 & 3.6 & 4.73 & 4.24 & 7.42 & 2.12 & 4.59 & 1.0 & 1.6 & 0.6 & 1.07 & 0.84 & 1.93 & 0.94 & 1.24 \\
\hline 4 & 4.6 & 8.3 & 2.0 & 4.97 & 4.54 & 11.35 & 3.39 & 6.43 & 1.0 & 1.3 & 0.6 & 0.97 & 0.92 & 2.20 & 0.86 & 1.33 \\
\hline 5 & 3.9 & 5.9 & 1.6 & 3.80 & 3.87 & 6.77 & 1.93 & 4.19 & 0.0 & 1.3 & 0.6 & 0.63 & 0 & 1.23 & 0.74 & 0.66 \\
\hline Mean & \multicolumn{4}{|c|}{5.882 .13} & 3.59 & 7.97 & 2.35 & & 1.43 & 2.17 & 1.10 & & 1.32 & 2.93 & 1.19 & \\
\hline $\begin{array}{c}\text { L.S.D.5\% } \\
\text { BA } \\
\text { Gamma } \\
\text { Interaction }\end{array}$ & \multicolumn{4}{|c|}{$\begin{array}{l}0.56 \\
0.98 \\
1.39\end{array}$} & \multicolumn{4}{|c|}{$\begin{array}{l}0.63 \\
1.09 \\
1.55\end{array}$} & \multicolumn{4}{|c|}{$\begin{array}{l}0.22 \\
0.38 \\
0.53\end{array}$} & \multicolumn{4}{|c|}{$\begin{array}{l}0.37 \\
0.64 \\
0.91\end{array}$} \\
\hline
\end{tabular}


Effect of gamma rays on propagation of Zantedeschia aethiopica.

Table(3):Effect of TDZ and three doses of gamma rays on Zantedeschia aethiopica shoot number, shoot length, root number and root length after 8 weeks (average of two seasons)

\begin{tabular}{|c|c|c|c|c|c|c|c|c|c|c|c|c|c|c|c|c|}
\hline \multirow{3}{*}{ TDZ mg/l } & \multicolumn{4}{|c|}{ Shoot number } & \multicolumn{4}{|c|}{ Shoot length(cm) } & \multicolumn{4}{|c|}{ Root number } & \multicolumn{4}{|c|}{ Root length(cm) } \\
\hline & \multicolumn{16}{|c|}{ Doses of gamma rays ( $\mathrm{Kr}$ ) } \\
\hline & 0 & 3 & 6 & Mean & 0 & 3 & 6 & Mean & 0 & 3 & 6 & Mean & 0 & 3 & 6 & Mean \\
\hline 0 & 1.9 & 3.6 & 1.3 & 2.27 & 2.34 & 5.85 & 1.75 & 3.31 & 3.3 & 4.0 & 2.3 & 3.20 & 2.63 & 4.04 & 1.97 & 2.88 \\
\hline 1 & 2.0 & 4.3 & 1.6 & 2.63 & 2.82 & 7.05 & 2.11 & 3.99 & 1.3 & 2.0 & 1.0 & 1.43 & 1.74 & 3.28 & 2.60 & 2.54 \\
\hline 2 & 2.3 & 4.6 & 1.6 & 2.83 & 3.15 & 7.87 & 2.36 & 4.46 & 1.6 & 2.6 & 1.3 & 1.83 & 2.56 & 3.49 & 3.32 & 3.12 \\
\hline 3 & 3.6 & 7.3 & 2.9 & 4.60 & 4.13 & 10.32 & 3.09 & 5.85 & 2.6 & 2.9 & 1.6 & 2.37 & 3.61 & 5.00 & 3.71 & 4.11 \\
\hline 4 & 3.3 & 4.9 & 1.6 & 3.27 & 3.86 & 6.75 & 1.93 & 4.18 & 3.9 & 5.0 & 2.6 & 3.83 & 3.33 & 5.24 & 4.16 & 4.24 \\
\hline 5 & 3.0 & 4.6 & 1.3 & 2.97 & 3.52 & 6.16 & 1.76 & 3.81 & 3.3 & 3.9 & 2.0 & 3.07 & 3.01 & 4.75 & 3.23 & 3.66 \\
\hline Mean & 2.68 & 4.88 & 1.72 & & 3.30 & 7.33 & 2.17 & & 2.67 & 3.40 & 1.80 & & 2.81 & 4.30 & 3.17 & \\
\hline L.S.D. $5 \%$ & \multirow{4}{*}{\multicolumn{4}{|c|}{$\begin{array}{l}0.36 \\
0.64 \\
0.90 \\
\end{array}$}} & \multirow{4}{*}{\multicolumn{4}{|c|}{$\begin{array}{l}0.49 \\
0.85 \\
1.20\end{array}$}} & \multirow{4}{*}{\multicolumn{4}{|c|}{$\begin{array}{l}0.22 \\
0.38 \\
0.54\end{array}$}} & \multirow{4}{*}{\multicolumn{4}{|c|}{$\begin{array}{c}0.28 \\
0.49 \\
07\end{array}$}} \\
\hline TDZ & & & & & & & & & & & & & & & & \\
\hline Gamma & & & & & & & & & & & & & & & & \\
\hline Interaction & & & & & & & & & & & & & & & & \\
\hline
\end{tabular}

Table(4):Effect of NAA and three doses of gamma rays on Zantedeschia aethiopica shoot number, shoot length, root number and root length after 8 weeks (average of two seasons)

\begin{tabular}{|c|c|c|c|c|c|c|c|c|c|c|c|c|c|c|c|c|}
\hline \multirow{3}{*}{ TDZ mg/l } & \multicolumn{4}{|c|}{ Shoot number } & \multicolumn{4}{|c|}{ Shoot length(cm) } & \multicolumn{4}{|c|}{ Root number } & \multicolumn{4}{|c|}{ Root length(cm) } \\
\hline & \multicolumn{16}{|c|}{ Doses of gamma rays ( $\mathrm{Kr}$ ) } \\
\hline & 0 & 3 & 6 & Mean & 0 & 3 & 6 & Mean & 0 & 3 & 6 & Mean & 0 & 3 & 6 & Mean \\
\hline 0 & 1.9 & 3.6 & 1.3 & 2.27 & 2.34 & 5.85 & 1.75 & 3.31 & 3.3 & 4.0 & 2.3 & 3.20 & 2.63 & 4.04 & 1.97 & 2.88 \\
\hline 1 & 1.6 & 3.0 & 1.3 & 1.97 & 2.17 & 5.43 & 1.62 & 3.07 & 3.9 & 5.6 & 4.6 & 4.70 & 3.35 & 6.84 & 4.73 & 4.97 \\
\hline 2 & 1.6 & 3.6 & 1.3 & 2.17 & 2.42 & 6.06 & 1.81 & 3.43 & 3.9 & 6.0 & 4.9 & 4.93 & 4.24 & 7.27 & 5.82 & 5.78 \\
\hline 3 & 2.6 & 3.6 & 2.0 & 2.73 & 2.97 & 5.19 & 1.48 & 3.22 & 4.6 & 6.3 & 5.6 & 5.50 & 5.37 & 7.85 & 6.52 & 6.58 \\
\hline 4 & 2.6 & 4.9 & 1.3 & 2.93 & 3.18 & 7.95 & 2.37 & 4.50 & 4.9 & 6.9 & 5.6 & 5.80 & 5.83 & 8.36 & 7.24 & 7.14 \\
\hline 5 & 2.3 & 3.3 & 0.9 & 2.17 & 2.71 & 4.74 & 1.35 & 2.93 & 5.9 & 7.6 & 6.0 & 6.50 & 6.96 & 9.72 & 7.77 & 8.15 \\
\hline Mean & 2.10 & 3.67 & 1.35 & & 2.63 & 5.87 & 1.73 & & 4.42 & 6.07 & 4.83 & & 4.73 & 7.35 & 5.68 & \\
\hline $\begin{array}{c}\text { L.S.D.5\% } \\
\text { TDZ } \\
\text { Gamma } \\
\text { Interaction }\end{array}$ & \multicolumn{4}{|c|}{$\begin{array}{l}0.3 \\
0.53 \\
0.75\end{array}$} & \multicolumn{4}{|c|}{$\begin{array}{c}0.4 \\
0.69 \\
0.98\end{array}$} & \multicolumn{4}{|c|}{$\begin{array}{l}0.3 \\
0.5 \\
0.7\end{array}$} & \multicolumn{4}{|c|}{$\begin{array}{l}0.36 \\
0.61 \\
0.86\end{array}$} \\
\hline
\end{tabular}


but the least number of roots and length was formed by $6.0 \mathrm{Kr}$ irradiation dose combined with $0.0 \mathrm{mg} / \mathrm{l} \mathrm{NAA}$, based on the average of the two seasons.

\section{REFERENCES}

Abu El-Leil E.F. (2008). Effect of 2,6-dinitro aniline and gamma rays on propagation of Nigella sativa and Cuminum cyminum L. plants MSc. Thesis, Dept. Ornam. Hort., Fac. Agric, Cairo Univ.

Arafa A. S. and Ebrahim M. K. H. (2001). Determination of the optimal conditions required for micropropagation and rhizome formation of calla (Zantedeschia aethiopica L. Spreng). J. Agric. Sci., Mansoura Univ., 26 (1): 413-425.

Badr M., Abdel-Masoud B. A. and Omer S. S. (2004). Growth, flowering and induced variability in Gompherna globosa L. plant grown from dry and water soaked seeds treated with gamma rays. Alex. J. Agric. Res., 49 (1): 49-70.

Bakry K. H. A. and Ismail F. H. (2002). Presowing treatments of papaya seeds as influenced by some chemicals and irradiation on germination, growth, flowering, sex expression and fruit quality. Proc. $2^{n d}$. Conf. Hort. Sci., Kafr El- Sheikh, Tanta Univ., Egypt, Vol 2 (3): 683-699.

Bryan J.E. (2002). Bulbs. (Rev. Ed.). Timber Press, Portland, Oregon.

Chang H.S., Chakrabarty D., Hahn E.J. and Paek K. Y. (2003). Micropropagation of calla lily (Zantedeschia albomaculata) via in vitro shoot tip proliferation. In vitro Cellular and Development biology plant , 39(2): 129-134.

Corr J. M. and Wilkins H. F. (2005). Floriculture Principles and Species. $2^{\text {nd }}$ ed. Pearson, Prentice Hall,. New Jersey.

Ebrahim M. K. H. (2004). Comparison, determination and optimizing the conditions required for rhizome and shoot formation, and flowering of in vitro cultured calla explants. Scientia Horticulturae 101 (3). 305-313.

El-Shakhs M. H., El-Nagger A. A. M. and ElFoully A. F. A. (2007). Response of some ornamental palm seeds to gamma irradiation. J. Agric. Sci., Mansoura Univ., 32 (10): 9629 -9639 .
El-Shamy M.A., El-Feky A.H.M. and Eliwa N.Y.L. (2008) Propagation of calla lily plants by tissue culture technique, Bull. Fac. Agric., Cairo Univ.,60:99-105.

Fereol L., Louis S. and Luce L. (1996). Effects of gamma radiation on in vitro plantlets of Alpinia purpurata. J. HortSci., 71 (2): 243247.

Khalil M. Y., El-Sherbeny S. E. and Hussein M.S. (2001). Growth, yield and chemical constituents of some medicinal plants in relation to gamma irradiation. Egypt J.Hort., 28,(3). 355-369.

Koech A. A., lsutsa D. K. and Wu. Q. (2002). Explants, sucrose and hormones influence In Vitro regeneration and rooting of Calla Lily (Zantedeschia albomaculata Spreng.). Jomo Kenyatta University of Agriculture and Technology (JKUAT), $6^{\text {th }}$ to $9^{\text {th }}$ August 2002, 75-84.

Kovacs E. and Keresztes A. (2002). Effect of gamma and $\mathrm{UV}-\mathrm{B} / \mathrm{C}$ radiation on plant cells . Micron. (33) :199-210.

Murashige T. and Skoog F. ( 1962). A revised medium for rapid growth and bioassays with tobacco tissue culture. Physiol. Plant. 15, 473-496.

Niederwieser J.G., Kleynhans R. and Hancke F.L.(2002). Development of new flower bulb crop in South Africa. Acta Hort. 570:67-73.

Puchooa D. (2005). In vitro mutation breeding of Anthurium by gamma radiation .Int. J. Agri. Biol., Vol. 7, No. 1. : 11-20.

SAS institute (1994). SAS/STAT User's Guide ver. 6. 04, $4^{\text {th }}$ Ed. SAS. Inst. Inc Gorg. N. C, U.S.A.

Seung G. W., Byung Y. C., Kim Ja., Kim Ji., Baek M., Lee Ju. and Kim Y. (2007). Effects of gamma irradiation on morphological changes and biological responses in plants. Micron 38 (2007) 553-564.

Snedecor G. W. and Cochran W. G. (1980). Statistical Methods .The Iowa State Univ. Press, Ames Iowa, U.S.A.

Tangpong P., Taychasinpitak T., Jompuk C. and Jompuk P. (2009). Effects of acute and chronic gamma irradiations on in vitro culture of Anubias congensis N.E. Brown . Kasetsart J. (Nat. Sci.). 43 : 449 - 457. 
تأثير أشعة جاما على اكثار نبات الكلا (Zantedeschia aethiopica Spreng) بواسطة تقنية زراعة الأنسجة

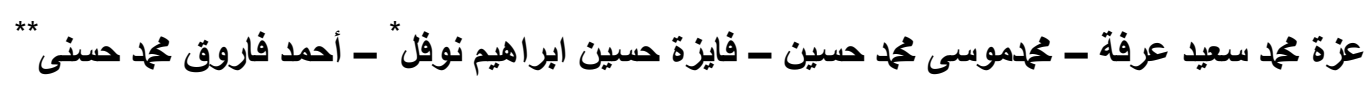

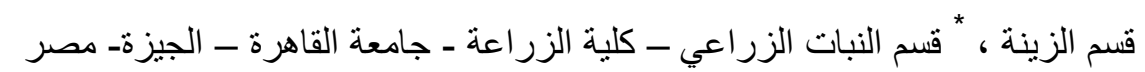

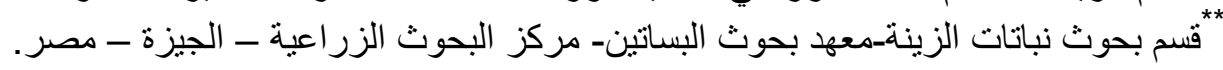

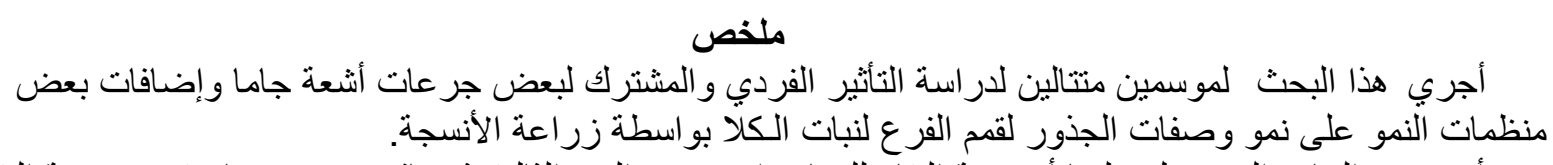

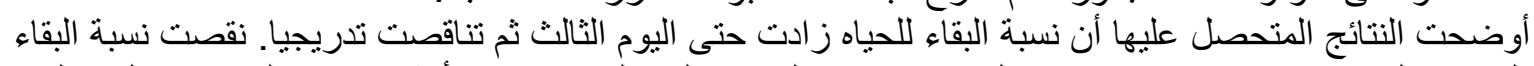

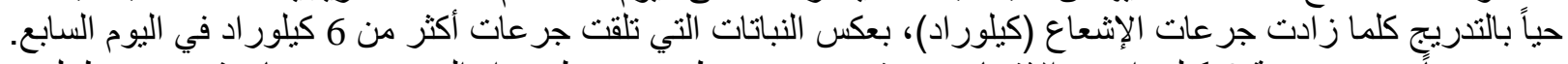

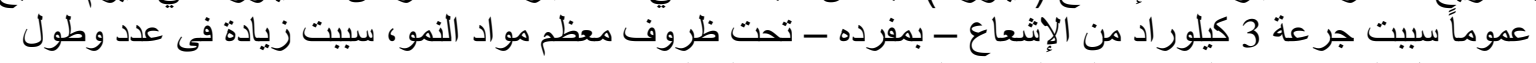

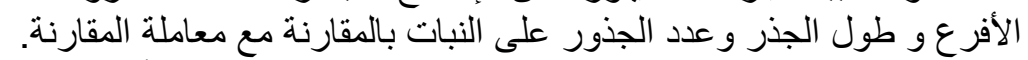

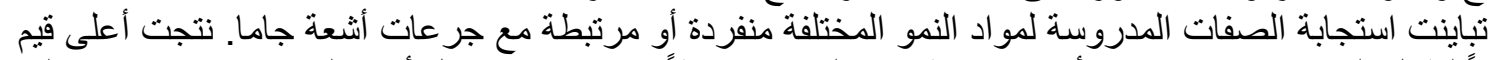

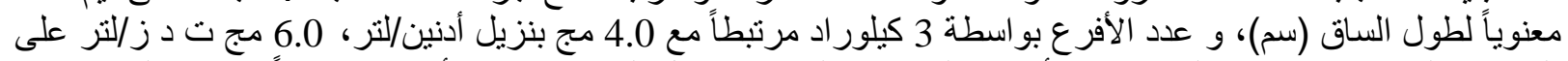

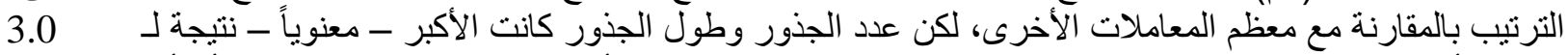

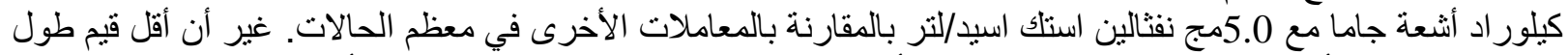

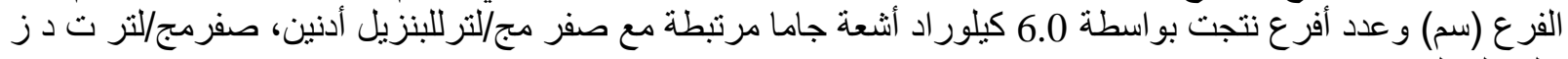
على التو الي. المجلة العلميةّة لكلية الزراعة - جامعة القاهرة - المجلا (62) العدد الثالث (يوليو 2011):355-361. 